\title{
Are health care policies for COVID-19 evidence-based?
}

Sergio Bonini ${ }^{1}$ and Silvana Fiorito ${ }^{1}$

${ }^{1}$ Istituto di Farmacologia Traslazionale Consiglio Nazionale delle Ricerche

March 6, 2022

\section{Hosted file}

Editorial.docx available at https://authorea.com/users/318922/articles/558789-are-healthcare-policies-for-covid-19-evidence-based 